Rev. Int. Contam. Ambie. 36 (4) 857-864, 2020

https://doi.org/10.20937/RICA.53659

\title{
POTENTIAL MOBILITY AND TOXICITY RISK OF METAL POLLUTANTS IN SOILS FROM A TROPICAL AREA AFFECTED BY INDUSTRIAL WASTES
}

Movilidad potencial y riesgo de toxicidad de contaminantes metálicos en suelos de una zona tropical afectada por desechos industriales

\author{
Ricardo SOARES ${ }^{1,2 *}$, Maria Carla BARRETO SANTOS ${ }^{2,3}$, John Edmund Lewis MADDOCK ${ }^{2}$, \\ Wilson MACHADO ${ }^{2}$, Luiz Carlos BERTOLINO ${ }^{4}$, David Vilas BOAS DE CAMPOS ${ }^{5}$, \\ Aline SOARES FREIRE ${ }^{6}$ and Ricardo ERTHAL SANTELLI ${ }^{6}$
}

${ }^{1}$ State Environmental Institute (INEA), 103 Venezuela Avenue, Saúde, Rio de Janeiro CEP 20081-312, Brazil.

${ }^{2}$ Department of Geochemistry, Fluminense Federal University, Niterói, Rio de Janeiro, CEP 24020-150, Brazil.

${ }^{3}$ Department of Geography of Campos dos Goytacazes, Fluminense Federal University, Campos dos Goytacazes, Rio de Janeiro, CEP 28010-385, Brazil.

${ }^{4}$ Mineral Technology Center (CETEM), Ilha do Fundão, Rio de Janeiro, 21941-908, Brazil.

${ }^{5}$ EMBRAPA Solos, Jardim Botânico, Rio de Janeiro, CEP 22460-000, Brazil.

${ }^{6}$ Department of Analytical Chemistry, Federal University of Rio de Janeiro, Technology Center, University City, Ilha do Fundão, Rio de Janeiro State, CEP 21941-909, Brazil.

*Author for correspondence: ricardosoaresuff@gmail.com

(Received: June 2019; accepted: April 2020)

Key words: soil pollution, industrial residues, metal contaminants, vertical mobility.

\begin{abstract}
The potential mobility of $\mathrm{Cd}, \mathrm{Cr}, \mathrm{Cu}, \mathrm{Ni}, \mathrm{Pb}$ and $\mathrm{Zn}$ in soils severely impacted by inadequate storage of industrial wastes in Rio de Janeiro State (Brazil) was evaluated by applying the Toxicity Characteristic Leaching Procedure (TCLP). This procedure allowed the estimation of toxicity risks for $\mathrm{Cd}, \mathrm{Cr}$ and $\mathrm{Pb}$. In a contamination hotspot within the study area, the following order of metal concentrations was observed: $\mathrm{Pb}>$ $\mathrm{Zn}>\mathrm{Cu}>\mathrm{Ni}>\mathrm{Cd}>\mathrm{Cr}$, with significantly higher values than observed for a control site. Decades of soil exposure to wastes implied TCLP results for $\mathrm{Pb}$ above $300 \mathrm{mg} / \mathrm{L}$ in this hotspot, which exceed the TCLP regulatory threshold in two orders of magnitude, while $\mathrm{Cd}$ (up to $0.8 \mathrm{mg} / \mathrm{L}$ ) and $\mathrm{Cr}$ (up to $0.3 \mathrm{mg} / \mathrm{L}$ ) results were below the respective TCLP thresholds. Surface soil profile analysis $(0-30 \mathrm{~cm}$ depth) indicates that $\mathrm{Pb}$ verti$\mathrm{cal}$ migration occurs in the hotspot. TCLP concentrations of $\mathrm{Pb}$ were up to four orders of magnitude higher than the groundwater quality threshold preconized by Brazilian regulations for this metal $(0.01 \mathrm{mg} / \mathrm{L})$, suggesting that downward dispersion of large loadings of anthropogenic $\mathrm{Pb}$ is a major concern.
\end{abstract}

Palabras clave: contaminación del suelo, residuos industriales, contaminantes metálicos, movilidad vertical.

\section{RESUMEN}

La movilidad potencial de $\mathrm{Cd}, \mathrm{Cr}, \mathrm{Cu}, \mathrm{Ni}, \mathrm{Pb}$ y $\mathrm{Zn}$ en suelos gravemente afectados por el almacenamiento inadecuado de desechos industriales en el estado de Río de Janeiro, 
Brasil, se evaluó mediante la aplicación del procedimiento de lixiviación con características de toxicidad (TCLP, por sus siglas en inglés). Este procedimiento permitió la estimación de riesgos de toxicidad para $\mathrm{Cd}, \mathrm{Cr}$ y $\mathrm{Pb}$. En una zona de alta contaminación dentro del área de estudio, se observó el siguiente orden de concentraciones de metales: $\mathrm{Pb}>\mathrm{Zn}>\mathrm{Cu}>\mathrm{Ni}>\mathrm{Cd}>\mathrm{Cr}$, con valores significativamente más altos que los observados para un sitio de control. Décadas de exposición del suelo a desechos implicaron resultados de TCLP para $\mathrm{Pb}$ por encima de $300 \mathrm{mg} / \mathrm{L}$ en esta zona, los cuales exceden el umbral regulatorio de TCLP en dos órdenes de magnitud, mientras que los valores de Cd (hasta $0.8 \mathrm{mg} / \mathrm{L}$ ) y $\mathrm{Cr}$ (hasta $0.3 \mathrm{mg} / \mathrm{L}$ ) estuvieron por debajo de los umbrales de TCLP respectivos. El análisis del perfil del suelo superficial $(0-30 \mathrm{~cm}$ de profundidad) indica que la migración vertical de $\mathrm{Pb}$ se produce en la zona de alta contaminación. Las concentraciones de Pb obtenidas con el TCLP fueron hasta cuatro órdenes de magnitud más altas que el umbral de calidad del agua subterránea recomendado por las regulaciones brasileñas para este metal $(0.01 \mathrm{mg} / \mathrm{L})$, lo que sugiere que la dispersión descendente de grandes cargas de $\mathrm{Pb}$ antrópico es un problema importante.

\section{INTRODUCTION}

Trace metal pollution is a frequent anthropogenic impact affecting the soil quality, which can imply environmental and human health risks due to trace metal toxicity, e.g. associated to negative effects on soil fauna, contamination of agricultural production and deterioration of surface and groundwater quality (Wang et al. 2001, García-Guinea et al. 2010, Santos et al. 2014, 2017, Cui et al. 2016). However, total or pseudo-total concentrations do not allow an accurate estimate of these risks (Dungan and Dees 2009, Soares et al. 2009, 2017, 2018, Prica et al. 2010), and the information on metal contaminants mobility and toxicity to organisms is largely desirable to improve soil management decisions (Kede et al. 2008, 2014, Fontes and Santos 2010).

A large number of metal partial extraction procedures have been reported in the literature (e.g., Rao et al. 2008, Perlatti et al. 2016, Soares et al. 2018, Weber et al. 2018), while single leaching procedures are generally used to define mobility and toxicity of pollutants in soils, sediments and waste materials (Kede et al. 2008, Prica et al. 2010, Ahmad et al. 2012). One of these procedures is the Toxicity Characteristic Leaching Procedure (TCLP) proposed by the US Environmental Protection Agency (US-EPA 1992), which has been frequently adopted due to its ability to simulate the effect of wastes interactions with low molecular weight organic acids that can mobilize toxic trace metals (Lima and Bernárdez 2011, Macías et al. 2012, Sethurajan et al. 2016).

As an example of a critical case of soil exposure to metal contamination due to multiple anthropogenic sources, the Centro Tecnológico de Resíduos (CENTRES), located in the Rio de Janeiro State, southeastern Brazil, operated between 1987 and 1998 as a provisional storage area of industrial wastes that were not adequately managed (Santos et al. 2014, Soares et al. 2017, 2018). Despite the restrictions established by environmental licensing policies, CENTRES rented part of its area for a waste treatment plant contaminated by askarel in 1991 (Santos et al. 2014, Soares et al. 2017, 2018), besides contamination by other products of high toxicity, such as tetraethyl lead and diverse industrial metal refuses (Pinto 2002, Soares et al. 2018). Consequently, the CENTRES soils present pseudo-total concentrations of copper, nickel, lead and zinc exceeding the limits established by the Brazilian legislation (CONAMA 2009), implying a soil classification as highly degraded that requires immediate remediation (Soares et al. 2018).

This study aims to apply the TCLP approach for $\mathrm{Cd}, \mathrm{Cr}, \mathrm{Cu}, \mathrm{Ni}, \mathrm{Pb}$ and $\mathrm{Zn}$ in soils from the CENTRES area, after more than 20 years of industrial waste pollution, comparing data from a pollution hotspot with nearby sites within this area. In this sense, the same samples previously analyzed for metal pseudo-total concentrations by Soares et al. (2018) were analyzed to perform a TCLP-based assessment of metal mobility and toxicity risks in surface soil columns.

\section{MATERIAL AND METHODS}

\section{Study area}

The study area (22 $\left.42^{\prime} 57^{\prime \prime} \mathrm{S}, 43^{\circ} 33^{\prime} 18^{\prime \prime} \mathrm{W}\right)$ features a hot and humid climate (Aw) according to the Köppen classification. It has yellow clay soils, predominantly with sandy clay loam texture, strong drainage and mineralogical assemblage consisting 
of quartz, kaolinite, muscovite, illite, halloysite and vermiculite (Soares et al. 2018). Figure 1 indicates the positions of sampling sites (P1 to P7). These soils have a $\mathrm{pH}_{(\mathrm{H} 2 \mathrm{O})}$ range from acidic to near neutral (3.8 to 6.9), with low total organic carbon contents (TOC $=6$ to $41 \mathrm{~g} / \mathrm{kg}$ ) and low cation exchange capacity $\left(\mathrm{CEC}=6.4\right.$ to $\left.11.2 \mathrm{cmol}_{\mathrm{c}} / \mathrm{dm}\right)$ for all sites (Soares et al. 2018).

\section{Sampling}

Seven samples of surface soils $(0-10 \mathrm{~cm})$ from the CENTRES storage area were collected in triplicate (samples P1 to P7; Fig. 1). To evaluate a possible migration of metal pollutants into deeper soil layers, additional triplicate samples were collected from two subsurface depth intervals $(10-20$ and $20-30 \mathrm{~cm})$ from the last three sampling stations mentioned above. These subsurface samples were identified as P5.1, P6.1 and P7.1 (10-20 cm) and P5.2, P6.2 and P7.2 $(20-30 \mathrm{~cm})$. Soil sampling was carried out following the procedures suggested by the Brazilian Society of Soil Sciences (Santos et al. 2013). All samples are characterized as urban soils, except for P4, which was chosen as control, considering its location at a more elevated position without exposure to hazardous materials.



Fig. 1. Sampling sites (P1 to $\mathrm{P} 7)$ location in the CENTRES area, Rio de Janeiro State, Brazil.

The soil samples were oven dried under artificial air circulation at a temperature of $45{ }^{\circ} \mathrm{C}$ for $24 \mathrm{~h}$ and sieved in a $2.0 \mathrm{~mm}$ mesh. The soil fractions not retained on the sieve, which corresponded to the thin air-dried soil, were macerated until a homogeneously fine texture was obtained.

\section{US-EPA Toxicity Characteristic Leaching Pro- cedure}

This study adopted the US-EPA Method 1311, as modified by Kede et al. (2008) for the TCLP application. Soil subsamples of about $2.5 \mathrm{~g}$ were submitted to agitation for $18 \mathrm{~h}$ at room temperature in an acetic-acetate $\mathrm{pH}$ buffer solution $(\mathrm{pH}=4.93 \pm 0.05)$, resulting in a final volume of $50 \mathrm{~mL}$. According to US-EPA (1992), results exceeding the thresholds of $1.0 \mathrm{mg} / \mathrm{L}$ for $\mathrm{Cd}$ and $5.0 \mathrm{mg} / \mathrm{L}$ for $\mathrm{Pb}$ and $\mathrm{Cr}$ in the obtained extractions are considered hazardous.

\section{Determination of metal concentrations by ICP- OES}

The concentrations of $\mathrm{Cd}, \mathrm{Cr}, \mathrm{Cu}, \mathrm{Ni}, \mathrm{Pb}$ and $\mathrm{Zn}$ in soil extracts were determined using an inductively coupled plasma optical emission spectrometer (ICPOES) Horiba Jobin Yvon model Ultima 2. Analytical detection limits (DL) were calculated according to the equation:

$D L=3 s / b$

where $s$ is the standard deviation of 10 white determinations and $b$ is the slope of the calibration curve (Soares et al. 2009). The obtained DLs were $0.005 \pm 0.001 \mathrm{mg} / \mathrm{L}(\mathrm{Cd}), 0.010 \pm 0.001 \mathrm{mg} / \mathrm{L}(\mathrm{Cr})$, $0.010 \pm 0.003 \mathrm{mg} / \mathrm{L}(\mathrm{Cu}), 0.010 \pm 0.002 \mathrm{mg} / \mathrm{L}(\mathrm{Ni})$, $0.010 \pm 0.002 \mathrm{mg} / \mathrm{L}(\mathrm{Pb})$, and $0.015 \pm 0.006 \mathrm{mg} / \mathrm{L}$ (Zn).

\section{Statistical analysis}

In order to verify the existence of significant differences in the results, an analysis of variance (ANOVA) followed by a Tukey test was carried out. The possible associations between concentrations of different metals were evaluated by Pearson correlation tests. Statistical analyses were performed using the software Statistica v. 7.0.

\section{RESULTS AND DISCUSSION}

The retention or mobilization of metals in soils may involve physical (e.g., filtration, diffusion, dispersion, dilution and absorption), chemical (e.g., precipitation/dissolution, adsorption/desorption, redox reactions, of complexation and cationic exchange), and biological (e.g., aerobic and anaerobic transformations) mechanisms (Sposito 2016, Alloway 2012, Kabata-Pendias and Pendias 2011). Considering that most samples had metal concentrations significantly above those obtained in the control sample (site P4) 
(Tukey test, $p<0.05$, Fig. 2), a higher metal mobility than under control soil conditions was clearly evidenced by the TCLP results. This evidences that the mechanisms cited above may be significantly affected by anthropogenic influences, as reflected by a different mobility of anthropogenic metal loadings within soils.

An anthropogenic alteration in metal mobility was also noted by Wang et al. (2001) in soils of an area used as a storage yard during more than 10 years for a scrap metal company in the South of Taiwan, where very high TCLP concentrations were found $(3.2 \mathrm{mg} / \mathrm{L}$ for $\mathrm{Cd}, 136 \mathrm{mg} / \mathrm{L}$ for $\mathrm{Cu}, 8.6 \mathrm{mg} / \mathrm{L}$ for $\mathrm{Ni}, 589 \mathrm{mg} / \mathrm{L}$ for $\mathrm{Pb}$ and $1576 \mathrm{mg} / \mathrm{L}$ for $\mathrm{Zn}$ ). Also, Ahmad et al.


(2012) assessed lead contamination in neutral soils $(\mathrm{pH}=6.5)$ from a military shooting area in South Korea and found concentrations of this metal about eight times above the US-EPA's regulatory TCLP value $(5 \mathrm{mg} / \mathrm{L})$.

Trace metal enrichment factors (EF) in relation to control soil values are certainly expected to be high in industrial areas. For example, industrial areas from Northwest China presented Ca EF exceeding 10, in relation to soil background ( $\mathrm{Li}$ et al. 2013). In the study sites, for almost all metals (except $\mathrm{Cr}$ ), the anthropogenically-affected TCLP results reached values one or two orders of magnitude higher than those from the control site, while $\mathrm{Cu}$ reached



Fig. 2. Average concentrations $(n=3)$ of metals obtained with TCLP. Error bars indicate standard deviations. Regulatory limits available for $\mathrm{Cd}, \mathrm{Cr}$ and $\mathrm{Pb}$ (USEPA 1996) are presented. Different superscript letters denote statistically significant differences (ANOVA followed by a Tukey test; $\mathrm{P}<0.05$ ). Note that $\mathrm{Pb}$ data are in a logarithmic scale. $\mathrm{DL}$ denotes the analytical detection limits (see the text for assessing the DL values). 
enrichments of four orders of magnitude and $\mathrm{Pb}$ reached enrichments of five orders of magnitude (Fig. 3). The high EFs observed are clear effects of anthropogenic interventions in the study area, particularly for station $\mathrm{P} 5$, but the concentrations of $\mathrm{Cd}$ and $\mathrm{Cr}$ are still below the respective TCLP regulatory values of US-EPA (1999). On the other hand, an unknown degree of metal transfer to deeper soil layers than those studied here, along the previous two decades, may possibly also contribute to explain the observed results.

A comparison of concentrations obtained in the TCLP test (Fig. 2) with the regulatory level from US-EPA for $\mathrm{Pb}(5 \mathrm{mg} / \mathrm{L})$ shows that concentrations


Fig. 3. Metal enrichment factors (EF) in relation to a reference site (site P4) for the average TCLP values reported in figure 3. ND denotes that EF was not determined since the analyzed sample presented a result below the analytical detection limit. Note that $\mathrm{Cu}$ EFs from site 5 samples are related to a control site concentration below the analytical detection limit. 
dustrial landfills for hazardous waste (US-EPA 1999, Lestan and Zapusek 2009, Prica et al. 2010, Yin et al. 2010, Macías et al. 2012, Cui et al. 2016).

Deep $\mathrm{Pb}$ migration in the contaminated soils can result in potential toxicological risk to groundwater (Dungan and Dees 2009). As a result, soil remediation is necessary in response to the evidenced environmental risks, considering the downward migration of $\mathrm{Pb}$ evidenced by the results from site P5 (Fig. 3). Alves et al. (2014) showed that even for waste foundry sands, which are mostly not hazardous, TCLP values may reach levels up to one order of magnitude higher than the groundwater maximum level preconized by Brazilian regulations for $\mathrm{Pb}(0.01$ $\mathrm{mg} / \mathrm{L}$; CONAMA 2009). In the case of CENTRES area, the maximum TCLP values for this metal suggest that downward dispersion of an anthropogenic loading four orders of magnitude higher than this ground water quality threshold is susceptible to occur.

Chen et al. (2002) study also demonstrated that $\mathrm{Pb}$ extracted by TCLP from surface soils under a riffle/ pistol shooting range in Florida also exceeded the values for hazardous waste provided by the US-EPA. The authors concluded that the leaching of $\mathrm{Pb}$ was controlled by the precipitation/dissolution reactions in the soil and that adsorption did not play an effective role in controlling the leaching of $\mathrm{Pb}$. An analogous interpretation is valid for the present study on soils from the CENTRES area.

The mobility of metals depends on the extent that the retention of these elements by solid phase sorption sites compensate their removal by solvents (Lestan and Zapusek 2009). It is documented that lead naturally has low mobility in soils as a result of its ability to form stable inner sphere complexes (Sposito 2016, Alloway 2012, Kabata-Pendias and Pendias 2011). However, the results of this study indicate that, after more than 20 years of contamination, the solid phases from site P5 surface soil were not able to retain such high $\mathrm{Pb}$ concentrations in strongly-bound forms, allowing its release from low-energy sites under the TCLP's slightly acidic conditions.

Tropical soils are generally composed of low activity clays (dominated by kaolinite) and have relatively low concentrations of organic matter and acidic $\mathrm{pH}$, as observed in the study area (Soares et al. 2018), contributing to explain the results of this study. Additionally, kaolinite and similar clay minerals are not able to result in efficient sorption of metals because of their low CEC, in contrast with the smectites and montmorillonites which are significantly more efficient as adsorbents in temperate soils (Fontes and Santos 2010, Ettler et al. 2011).

\section{CONCLUSIONS}

This evaluation of $\mathrm{Cd}, \mathrm{Cr}, \mathrm{Cu}, \mathrm{Ni}, \mathrm{Pb}$ and $\mathrm{Zn}$ potential mobility in soils from the CENTRES area revealed concentrations largely exceeding those from a control site. Results showed the following order of decreasing TCLP concentrations: $\mathrm{Pb}>\mathrm{Zn}>\mathrm{Cu}>\mathrm{Ni}$ $>\mathrm{Cd}>\mathrm{Cr} . \mathrm{Cu}$ and $\mathrm{Pb}$ reached enrichments factors corresponding to four and five orders of magnitude above the control soil values, respectively. The toxicity risks assessment for $\mathrm{Cd}, \mathrm{Cr}$ and $\mathrm{Pb}$, based on TCLP assumptions, demonstrated a severe impact by inadequate storage of industrial wastes in relation to $\mathrm{Pb}$ in a contamination hotspot within the study area, with TCLP results up to 76 times higher than the respective regulation value. The TCLP results for $\mathrm{Pb}$ reached levels above $300 \mathrm{mg} / \mathrm{L}$ in this hotspot. On the other hand, $\mathrm{Cd}$ (up to $0.8 \mathrm{mg} / \mathrm{L}$ ) and $\mathrm{Cr}$ (up to $0.3 \mathrm{mg} / \mathrm{L}$ ) results were below the TCLP regulatory values. The analysis of surface soil profiles $(0-30 \mathrm{~cm}$ depth) evidenced that downward dispersion of $\mathrm{Pb}$ is of major concern in the hotspot site. This mobilization susceptibility of hazardous levels of $\mathrm{Pb}$ implies major environmental concerns and requests the treatment of the hotspot soil as a hazardous waste. This risk may be accentuated by other metals (such as $\mathrm{Cu}, \mathrm{Cd}$, $\mathrm{Ni}$ and $\mathrm{Zn}$ ) that have no threshold values stablished by the US-EPA TCLP, but also presented elevated concentrations downward.

\section{REFERENCES}

Ahmad M., Hashimotob Y., Moonc D.H., Leea S.S. and Oka Y.S. (2012). Immobilization of lead in Korean military shooting range soil using eggshell waste: An integrated mechanistic approach. J. Haz. Mater. 209-210, 392-401. https://doi.org/10.1016/j. jhazmat.2012.01.047

Alloway B.J. (2012). Heavy metals in soils. Springer, New York, USA, 368 pp.

Alves B.S.Q., Dungan R.S., Carnin R.L.P., Galvez R. and Pinto C.R.S.C. (2014). Metals in waste foundry sands and an evaluation of their leaching and transport to groundwater. Water Air Soil Pollut. 225, 1963-1974. https://doi.org/10.1007/s11270-014-1963-4

Chen M., Daroub S.H., Ma L.Q., Harris W.G. and Cao X.D. (2002). Characterization of lead in soils of a rifle/pistol shooting range in central Florida, USA. Soil Sediment Contam. 11, 1-17. https://doi. org/10.1080/20025891106664

CONAMA (2009). Rules on criteria and soil quality values for chemical substances and establishes guidelines for 
the environmental management of areas contaminated by these substances as a result of anthropogenic activities. Brazilian CONAMA Resolution n. 420. Brasília, Brazil, 20 pp.

Cui H., Fan Y., Fang G., Zhang H., Su B. and Zhou J. (2016). Leachability, availability and bioaccessibility of $\mathrm{Cu}$ and $\mathrm{Cd}$ in a contaminated soil treated with apatite, lime and charcoal: A five-year field experiment. Ecotoxicol. Environ. Safety 134 (1), 148-155. https:// doi.org/10.1016/j.ecoenv.2016.07.005

Dungan, R.S. and Dees N.H. (2009). The characterization of total and leachable metals in foundry molding sands. J. Environ. Manage. 90 (1), 539-548. https:// doi.org/10.1016/j.jenvman.2007.12.004

Ettler V., Mihaljevic M., Kribek B., Majer V. and Sebek O. (2011). Tracing the spatial distribution and mobility of metal/metalloid contaminants in Oxisols in the vicinity of the Nkana copper smelter, Copperbelt province, Zambia. Geoderma 16 (2), 73-84. https:// doi.org/10.1016/j.geoderma.2011.05.014

Fontes M.P.F. and Santos G.C. (2010). Lability and sorption of heavy metals as related to chemical, physical and mineralogical characteristics of highly weathered soils. J. Soil Sediment 10, 774-786. https://doi. org/10.1007/s11368-009-0157-y

García-Guinea J., Correcher V., Recio-Vázquez L., Crespo-Feo E., González-Martín R. and Tormo L. (2010). Influence of accumulation of heaps of steel slag on the environment: determination of heavy metals content in the soils. An. Acad. Bras. Ciênc. 82 (2), 267-277. https://doi.org/10.1590/S0001-37652010000200003

Kabata-Pendias A. and Pendias H. (2011) Trace Elements in Soils and Plants. 4th ed. CRC Press, Boca Raton FL, USA, 548 pp.

Kede M.L.F., Moreira J.C., Mavropoulos E., Rossi A.M., Bertolino L.C., Pérez D.V. and Rocha N.C.C. (2008). Study of the behavior of lead in Brazilian soil with presence of micro aggregates treated with phosphate: contributions to the remediation of contaminated sites. Quím. Nova 31, 579-584. https://doi.org/10.1590/ S0100-40422008000300022

Kede M.L.F., Correia F.V., Conceição P.F., Salles S.F., Marques M., Moreira J.C. and Pérez D.V. (2014). Evaluation of mobility, bioavailability and toxicity of $\mathrm{Pb}$ and $\mathrm{Cd}$ in contaminated soil using TCLP, BCR and earthworms. Int. J. Environ. Res. Public Health 11 (11), 11528-11540. https://dx.doi.org/10.3390\%2Fijerph111111528

Kede M.L.F., Pérez D.V., Moreira J.C. and Marques M. (2016). Effect of phosphates on the bioavailability and phytotoxicity of $\mathrm{Pb}$ and $\mathrm{Cd}$ in contaminated soil and phytoextraction by Vetiver grass. J. Environ. Eng. 143, 3-11. https://doi.org/10.1061/(ASCE)EE.19437870.0001170
Lestan D. and Zapusek U. (2009). Fractionation, mobility and bio-accessibility of $\mathrm{Cu}, \mathrm{Zn}, \mathrm{Cd}, \mathrm{Pb}$ and $\mathrm{Ni}$ in aged artificial soil mixtures. Geoderma 154 (2) 164-169. https://doi.org/10.1006/j.geoderma.2009.10.012

Li X, Liu L., Wang Y., Luo G, Chen X., Yang X., Hall M.H.P., Guo R., Wang H., Cui J. and He X. (2013). Heavy metal contamination of urban soil in an old industrial city (Shenyang) in Northeast China. Geoderma 192, 50-58. https://doi.org/10.1016/j.geoderma.2012.08.011

Lima L.R.P.A. and Bernárdez L.A. (2011). Characterization of the lead smelter slag in Santo Amaro, Bahia, Brazil. J. Haz. Mater. 189 (3), 692-699. https://doi. org/10.1016/j.jhazmat.2011.02.091

Macías F., Caraballo M.A. and Nieto J.M. (2012). Environmental assessment and management of metal-rich wastes generated in acid mine drainage passive remediation systems. J. Haz. Mater. 229, 107-14. https:// doi.org/10.1016/j.jhazmat.2012.05.080

Perlatii F., Ferreira T.O., Sartor L. and Otero X.L. (2016). Copper biogeochemistry in response to rhizosphere soil processes under four native plant species growing spontaneously in an abandoned mine site in NE Brazil. Water Air Soil Pollut. 227 (5), 142-151. https://doi. org/10.1007/s11270-016-2840-0

Pinto E.M. (2002). Major difficulties of industrial waste management in the State of Rio de Janeiro: the case CENTRES - Waste Technology Center, located in the county of Queimados. Master Dissertation. Fluminense Federal University, Brazil, 95 pp.

Prica M., Dalmacija B., Agbaba J., Krcmar D., Trickovic J. and Karlovic E. (2010). Changes in metal availability during sediment oxidation and the correlation with the immobilization potential. Ecotoxicol. Environ. Safety 73, 1370-1377. https://doi.org/10.1016/j. ecoenv.2010.06.014

Rao C.R.M., Sahuquillo A. and Sánchez J.F.L. (2008). A Review of the different methods applied in environmental geochemistry for single and sequential extraction of trace elements in soils and related materials. Water Air Soil Pollut. 189 (4), 291-333. https://doi. org/10.1007/s11270-007-9564-0

Santos R.D., Lemos R C., Santos H.G., Ker J.C., Anjos L.H.C. and Shimizu S.H. (2013). Handbook of soil's collection and description out on the field. 6th ed. Brazilian Society of Soil Science, Campinas, Brazil, 100 pp.

Santos M.C.B, Maddock J.E.L., Bertolino L.C., Santelli R.E. and Soares R. (2014). Resíduo industrial: onde depositar? Ciência Hoje 53, 30-33. https://doi. org/10.1071/s11380-005-7866-1

Santos M.C.B., Kede M.L.F., Moreira J.C., Mavropoulos E., Rossi A.M., Bertolino L.C., Pérez D.V., Santelli R.E., Bielschowsky C. and Soares R. (2017). Evaluation of the toxicity and geochemical behavior of lead 
in contaminated soils of Santo Amaro da Purificação (BA) after phosphorus attenuation. Rev. Virtual Quim. 9 (5), 2135-2150. https://doi.org/10.21577/19846835.20170127

Sethurajan M., Huguenot D., Lens P.N., Horn H.A. and Hullebusch E.D. (2016). Fractionation and leachability of heavy metals from aged and recent $\mathrm{Zn}$ metallurgical leach residues from the Três Marias zinc plant (Minas Gerais, Brazil). Environ. Sci. Pollut. Res. 23 (8), 75047516. https://doi.org/10.1007/s11356-015-6014-1

Soares R., Carneiro M.C., Monteiro M.I.C., Junior S.S.H., Pontes F.V.M., Silva L.I.D., Neto A.A. and Santelli R.E. (2009). Simultaneous speciation of chromium by spectrophotometry and multicomponent analysis. Chem. Spec. Bioavail. 21 (3), 153-160. https://doi. org/10.3184/095422909X466095

Soares R., Santos M.C.B., Maddock J.E.L., Machado W.T.V., Bertolino L.C., Campos D.V.B., Freire A.S. and Santelli R.E. (2017). Evaluation of the geochemical behavior and environmental risk of metals in an area impacted by industrial waste in Queimados (RJ). Rev. Virtual Quim. 9 (5), 2151-2176. https://doi. org/10.21577/1984-6835.20170128

Soares R., Santos M.C.B., Maddock J.E.L., Bertolino L.C., Campos D.V.B., Monteiro M.I.C., Freire A.S. and Santelli R.R. (2018). Aqua regia as an alternative extractor for the environmental diagnosis of areas impacted by industrial waste: Case study CENTRES
(Queimados, RJ). Eng. Sanit. Amb. 23 (5) 995-1000. https://doi.org/10.1590/s1413-41522018167298

Sposito G. (2016). The Chemistry of Soils. 3rd ed. OUP USA, New York, USA, 272 pp.

US-EPA (1992). Toxicity Characteristic Leaching Procedure. U.S. Environmental Protection Agency Method 1311, 2nd ed. U.S. Gov. Print. Office, Washington DC, USA, 35 pp.

Vann N.K., Musson S.E. and Townsend T.G. (2006). Factors affecting TCLP lead leachability from computers CPUs. Waste Manage. 26 (3), 293-298. https://doi. org/10.1016/j.wasman.2005.06.016

Wang Y.M., Chen T.C., Yeh K.J. and Shue M.F. (2001). Stabilization of an elevated heavy metal contaminated site. J. Haz. Mater. 88 (1), 63-74. https://doi. org/10.1016/j.hazmat.11606241

Weber J., Dradrach A., Karcewska A. and Kocowicz A. (2018). The distribution of sequentially extracted $\mathrm{Cu}$, $\mathrm{Pb}$, and $\mathrm{Zn}$ fractions in Podzol profiles under dwarf pine of different stages of degradation in subalpine zone of Karkonosze (central Europe). J. Soil. Sediment. 18 (6), 2387-2398. https://doi.org/10.1007/s11368017-1715-3

Yin X., Saha U.K. and Ma L.Q. (2010). Effectiveness of best management practices in reducing $\mathrm{Pb}$-bullet weathering in the shooting range in Florida. J. Haz. Mater. 179 (3), 895-900. https://doi.org/10.1016/j. jhazmat.2010.03.089 